\title{
In Vitro Cytotoxic and Proapoptotic Activities of Anatolian Macrovipera Lebetina Obtusa (Dwigubski, 1832) Crude Venom on Cultured K562 Human Chronic Myelogenous Leukemia Cells
}

\author{
Faruk SUZERGOZ ${ }^{1}$, Nasit IGCI ${ }^{2}$, Cemal CAVUS ${ }^{1}$, Mehmet Z. YILDIZ ${ }^{3}$, \\ Mehmet B. COSKUN ${ }^{1}$, Bayram GOCMEN ${ }^{4}$ \\ ${ }^{1}$ Harran University Faculty of Arts and Science, Department of Biology, Sanliurfa \\ ${ }^{2}$ Nevsehir Hac1 Bektas Veli University Faculty of Arts and Sciences, \\ Department of Molecular Biology and Genetics, Nevsehir \\ ${ }^{3}$ Adiyaman University Faculty of Arts and Science, Department of Biology, Adiyaman \\ ${ }^{4}$ Ege University Faculty of Science, Department of Biology, Izmir, TURKEY
}

\begin{abstract}
In the context of searching for anticancer compounds in natural products, snake venom is one of the important sources for peptide/ protein based bioactive molecules. Proteins and peptides with anticancer activity were purified and identified from snake venoms. The aim of the present study was to determine the in vitro cytotoxicity of Macrovipera lebetina obtusa (Blunt-Nosed Viper) crude venom from southeastern Anatolia against K562 human chronic myelogenous leukemia (CML) cells by 3-(4,5-dimethylthiazol-2-yl)-2,5-diphenyltetrazolium bromide (MTT) and Adenosine tripohsphate (ATP) assays. Additionally, the apoptosis induction was assessed by morphological evaluation and immunohistochemical analysis for activated caspase-3. For histopahtological evaluation, haematoxylineosin, giemsa and papanicolau stains were used in combination. M. I. obtusa venom showed dose-dependent toxicity against K562 cells after $72 \mathrm{~h}$ treatment with different concentrations of crude venom. IC50 values were 0.45 and $0.37 \mu \mathrm{g} / \mathrm{mL}$ for MTT and ATP assays, respectively. Nuclear fragmentation and condensation, apoptotic bodies and activation of caspase-3, as an induction of apoptosis were also observed in K562 cells. Since apoptosis-inducing compounds are important for the treatment of cancer, further studies on Anatolian M. I. obtusa venom could result in the purification and identification of new proteins and peptides, which might have therapeutic value for the treatment of CML.
\end{abstract}

Keywords: Anticancer, Apoptosis, Blunt-nosed viper, Macrovipera lebetina obtusa, Snake venom

ÖZET

Anadolu'da Yayılış Gösteren Macrovipera lebetina obtusa (Dwigubski, 1832) Zehrinin K562 İnsan Kronik Myeloid Lösemi Hücreleri Üzerinde in vitro Sitotoksik ve Apoptotik Aktiviteleri

Doğal ürünlerde antikanser bileşiklerin araşııııması kapsamındaki çalışmalarda kullanılan önemli biyoaktif peptit/protein kaynaklarından biri de yılan zehridir. Yılan zehirlerinden antikanser etkili protein ve peptitler saflaştııımış ve tanımlanmıştır. Bu çalışmanın amacı, güneydoğu Anadolu bölgesinde bulunan Macrovipera lebetina obtusa (Koca Engerek) ham zehrinin K562 insan kronik myeloid lösemi (KML) hücreleri üzerinde in vitro sitotokik etkisinin 3-(4,5-dimethylthiazol-2-yl)-2,5-diphenyltetrazolium bromide (MTT) ve Adenosine tripohsphate (ATP) testleri ile belirlenmesidir. Ek olarak, morfolojik değerlendirme ve aktif kaspaz-3 immünohistokimyasal analizi ile zehrin apoptotik etkisi de değerlendirilmiştir. Histopatolojik değerlendirme için hematoksilen-eozin, gimza ve papanikolau boyaları kullanılmıştır. M. I. obtusa zehrinin farkı konsantrasyonlarılla 72 saatlik inkübasyon sonucunda K562 hücrelerine karşı doza bağlı toksisite görülmüştür. IC50 değerleri MTT ve ATP testleriyle sırasıyla 0.45 and $0.37 \mu \mathrm{g} / \mathrm{mL}$ olarak hesaplanmıştır. Ayrıca apoptoz uyarımının göstergeleri olarak nükleer fragmentasyon ve yoğunlaşma, apoptotik veziküller ve kaspaz-3 aktivasyonu gözlenmiştir. Apoptoza neden olan bileșiklerin kanser tedavisinde önemli bir yeri olması göz önünde bulundurulduğunda, Anadolu'da bulunan M. I. obtusa zehri üzerinde yapılacak detaylı çalışmalar KML tedavisinde terapötik potansiyeli olan yeni protein ve peptitlerin saflaştırlıp tanımlanmasıyla sonuçlanabilir.

Anahtar Kelimeler: Antikanser, Apopitoz, Koca engerek, Macrovipera lebetina obtusa, Yllan zehri 


\section{INTRODUCTION}

Cancer is one of the leading causes of disease-related death among humans in both developed and developing countries, accounting for 8.2 million deaths in 2012. According to the increase of the incidence of cancer from 2008 to 2012, it was projected that the number of cancer cases will increase high up to 25 million over the next two decades. ${ }^{1}$ Leukemia, the cancer of the blood cells (usually white blood cells), constitute approximately 3\% of all cancer types. ${ }^{2} \mathrm{~K} 562$ cell line is composed of undifferentiated blast cells, which has been firstly cultured from a patient with chronic myelogenous leukemia (CML) in blast crisis. ${ }^{3}$ Myelogenous leukemia can be defined as the cancer of the myeloid stem cells (myeloblasts), resulting in the increase of myeloid cells, erythroid cells and platelets. ${ }^{4}$

There has been a continuous effort in order to find anti-cancer agents. Natural bioactive molecule resources such as plants and animals are being searched for this purpose. Snake venom is one of the important sources of bioactive proteins and peptides with distinct pharmacological activities. ${ }^{5,6}$ Snake venom is a complex mixture consisting of mainly proteins and peptides and rich in enzymes. ${ }^{7}$ Composition of snake venoms vary at different levels, including inter/intra-specific, inter-genus, diet, age and sex-related variations. ${ }^{7,8}$ However, identified proteins from snake venoms to date can be grouped in major protein families. These include metalloproteinase, serine proteinase, L-amino acid oxidase (LAAO), hyaluronidase, phosphodiesterase, $5^{\prime}$-nucleotidase, arginine ester hydrolase, acetylcholinesterase and phospholipase $\mathrm{A}_{2}\left(\mathrm{PLA}_{2}\right)$ as enzymes; C-type lectin protein (CLP), disintegrin, cysteine-rich secretory protein (CRISP), natriuretic peptide, bradykinin potentiating peptide (BPP), myotoxin, neurotoxin, nerve growth factor (NGF), vascular endothelial growth factor (VEGF) and kunitz-type proteinase inhibitor as non-enzyme proteins and peptides. ${ }^{7}$

A considerable number of bioactive proteins have been identified from snake venoms which have potential therapeutic value against various diseases such as cancer, bacterial and fungal infections, cardiovascular disorders (e.g., acute coronary syndrome) and arthritis. ${ }^{5,69-14}$ With a special focus on anticancer activity, various snake venoms and pu- rified proteins (e.g., metalloprotease, disintegrin, $\mathrm{PLA}_{2}, \mathrm{LAAO}, \mathrm{CLP}$ ) have been shown to inhibit cancer progression in vitro and/or in vivo by affecting different cellular mechanisms, including apoptosis induction. ${ }^{15-22}$

The Blunt-Nosed Viper, Macrovipera lebetina (Linnaeus, 1758) has a distribution from northern Africa to Pakistan and from the Gulf of Oman to the Caspian Sea and Dagestan (Russia) with different subspecies, including the eastern part of Anatolia. In Turkey, according to the current accepted systematics, M. l. obtusa (Dwigubski, 1832) subspecies has a distribution in southern, eastern and northeastern Anatolia. ${ }^{23}$

Most of the previous studies related to snake venoms in Turkey are polyacrylamide gel electrophoresis-based comparisons. ${ }^{24,25}$ Recently, snake venom studies aiming to make biological and proteomic characterization have been done. ${ }^{8,26-30}$ This study aimed to investigate the in vitro cytotoxicity and proapoptotic activity of crude venom extracted from Anatolian M. l. obtusa against K562 human chronic myelogenous leukemia cancer cell line.

\section{MATERIALS AND METHODS}

\section{Snake Venom}

All experiments were performed with pooled venom extracted from two adult male $M$. l. obtusa which was collected from Şanlıurfa and Diyarbakır provinces (southeastern Turkey). Venoms were extracted following the appropriate procedures for venom sampling, without applying pressure to venom glands. Ethical permission for venom collection and handling of vipers was obtained from the Ege University Animal Experiments Ethics Committee (permit no. 2010-43). In addition, permission to collect vipers for venom sampling was obtained from the Republic of Turkey Ministry of Forest and Water Affairs. After extraction, individual venoms were pooled and centrifuged at 2,000 $\times \mathrm{g}$ at $4^{\circ} \mathrm{C}$ for $10 \mathrm{~min}$. The supernatant was immediately frozen at $-80^{\circ} \mathrm{C}$ and afterwards lyophilized by freeze-drying.

\section{Determination of the Protein Concentration}

Protein concentration was determined by the Bradford method using protein assay reagent (Bio-Rad, 
USA) with bovine serum albumin (Thermo Scientific, USA) as a standard. Sample and standards were measured at $595 \mathrm{~nm}$ by a spectrophotometer (SpectraMax, Molecular Devices, USA). The mean value of three measurements is given as a result.

\section{Cell Culture and in vitro Cytotoxicity Assay}

K562 human chronic myelogenous leukemia cells (ATCC) were grown and maintained in RPMI1640 (Sigma) medium supplemented with 10\% fetal bovine serum (Sigma), penicillin (100 U/L) and streptomycin $(100 \mathrm{mg} / \mathrm{L})(\mathrm{Sigma})$ at $37^{\circ} \mathrm{C}$ in humidified incubator with an atmosphere of 5\% $\mathrm{CO}_{2}$. The cells were cultured in 96-well cell culture microplates with an initial concentration of $10^{4}$ cells/well in $100 \mu \mathrm{L}$ of culture medium. Venom of M. l. obtusa was dissolved in PBS, serially diluted in culture medium and $10 \mu \mathrm{l} /$ well were added to to 96-well plates in triplicate order with the final concentration of $0.78,1.56,3.12,6.25,12.50$ and $25 \mu \mathrm{g} / \mathrm{mL} .10 \mu \mathrm{l}$ PBS was added to negative control wells. After venom treatment, incubation continued for $72 \mathrm{~h}$. Cytotoxicity of crude venom was determined by comparing two cytotoxicity assay, Adenosine tripohsphate (ATP) assay for quantitative detection of cellular ATP and 3-(4,5-dimethylthiazol-2-yl)-2,5-diphenyltetrazolium bromide (MTT) assays for cellular metabolic activity. ${ }^{31}$

The ATP assay is a luciferase driven bioluminescence assay and uses the highly sensitive "firefly" reaction to determine the level of cellular ATP as an indirect measure to assess the number of viable cells. The ATP content was determined according to the manufacturer's recommendation (Molecular Probe, Invitrogen, Germany). For this purpose, ATP was extracted from the cells, and then luciferin-luciferase was added. For luminescence determination, the microplates were measured using a count integration time of $5 \mathrm{~s}$ at luminometer (SpectraMax, Molecular Devices, USA). Luminescence measurements were directly related to ATP levels and the cell number.

The MTT technique was applied for cytotoxicity screening of the K562 cells growing in suspension culture. $10 \mu \mathrm{L}$ of $5 \mathrm{mg} / \mathrm{mL}$ MTT (Sigma) was added to each well. The mitochondria of viable cells converted the yellow MTT tetrazolium salt to a purple formazan. After $4 \mathrm{~h}$ incubation, the culture medium was removed, and $100 \mu \mathrm{L}$ of 2-propanol was added to dissolve the insoluble blue formazan precipitates produced by MTT reduction. The plate was shaken for $20 \mathrm{~min}$ on a plate shaker to ensure complete dissolution. The optical density of each well was measured at $570 \mathrm{~nm}$ using a spectrophotometer (SpectraMax, Molecular Devices).

\section{Determination of $\mathrm{IC}_{50}$ and Statistics}

The half maximal inhibitory concentration $\left(\mathrm{IC}_{50}\right)$ value, which was the concentration of crude venom causing $50 \%$ inhibition of cell growth in comparison with untreated controls, calculated by using percentage values of viable cells. Control values were set at $0 \%$ cytotoxicity. The percentage of cell viability against different venom doses was determined as follows:

Viable cells $(\%)=([$ Mean OD of the treated cells $]$ -[Mean OD of the blank]) / ([Mean OD of the control cells] - [Mean OD of the blank]) $\times 100$

$\mathrm{IC}_{50}$ was calculated by plotting the data using percentage inhibition and logarithmic transformed concentration values to obtain exponential equation. Student's t test with $95 \%$ confidence interval was performed to assess the significance of the changes in cell viability.

\section{Histopathology and Immunohistochemistry to Assess Apoptosis}

Histopathological analyses were carried out using the routine haematoxylin \& eosin (H\&E) (Sigma), giemsa (Sigma) and Papanicolau (PAP) (Sigma) staining procedures in combination. Venom treated $(25 \mu \mathrm{g} / \mathrm{mL}, 72 \mathrm{~h})$ and control K562 cell sections were examined by light microscopy (Olympus BX50, Japan). Immunohistochemical detection of apoptosis-related protein caspase-3 was carried out in K562 cells. Venom treated $(25 \mu \mathrm{g} / \mathrm{mL}$, $72 \mathrm{~h}$ ) and untreated K562 cells were reacted with caspase-3 specific antibody (Biocare, USA), which recognized large fragments $(17 / 19 \mathrm{kDa})$ of activated caspase-3. The primary antibody for caspase-3 (Biocare) was applied at a dilution of 1:250 and incubated at $37^{\circ} \mathrm{C}$ for $60 \mathrm{~min}$. Secondary antibody and chromogen (DAP) were used according to the manufacturer's instructions. Finally, sections were counterstained with haematoxylin. 


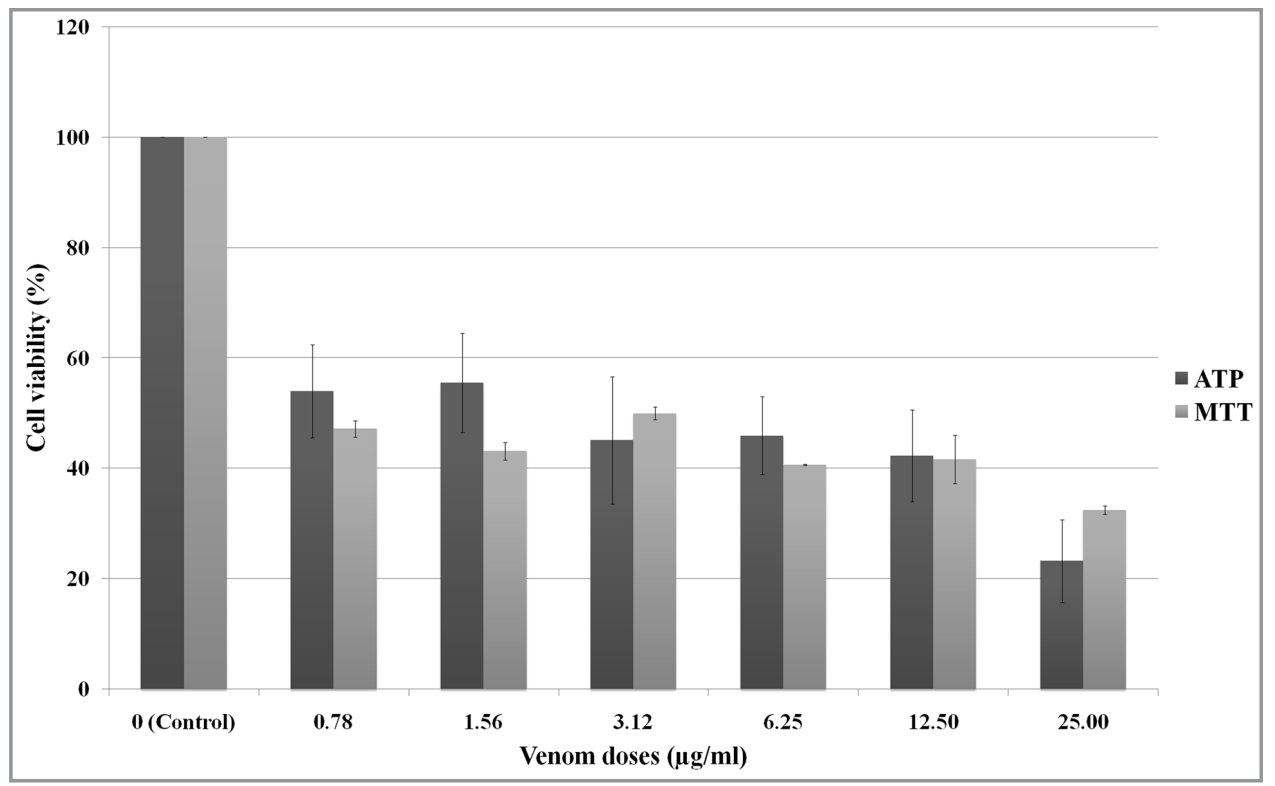

Figure 1. MTT and ATP assay results showing dose-dependent inhibitory effect of $M$. I. obtusa crude venom on K562 cells after $72 \mathrm{~h}$ exposure. Decrease in the viability of the cells is statistically significant $(p<0.05)$ for all doses, compared to control.

\section{RESULTS}

The protein concentration of $1 \mathrm{mg} / \mathrm{mL}$ pooled venom of M. l. obtusa was calculated as $0.75 \mathrm{mg} /$ $\mathrm{mL}$. Serially diluted crude venom concentrations between 0.78 and $25 \mu \mathrm{g} / \mathrm{mL}$ were used for cytotoxicity assays. According to the results of MTT and ATP assays, M. l. obtusa venom showed dosedependent cytotoxicity against K562 cells (Figure 1). Cell membrane disruption and granulation were observed after venom treatment. Figure 2 shows K562 cells after incubation with MTT and the formation of formazan crystals. MTT and ATP assay results were in correlation. $\mathrm{IC}_{50}$ values were calculated as 0.45 and $0.37 \mu \mathrm{g} / \mathrm{mL}$ for MTT and ATP assays, respectively. At the first dose $(0.78 \mu \mathrm{g} / \mathrm{mL})$ statistically significant decrease in the cell viability was observed compared to the control with \% inhibition values as 46 and $52.8 \%$ for MTT and ATP assays, respectively. Inhibition of the cell viability was reached at $67.6 \%$ (MTT) and $76.8 \%$ (ATP) at the highest venom dose $(25 \mu \mathrm{g} / \mathrm{mL})$ (Figure 1).

To assess the induction of apoptosis, histopathological and immunohistochemical analyses were carried out. For morphological/histopathological evaluation, H\&E, giemsa and PAP stained slides were prepared after $72 \mathrm{~h}$ treatment with $25 \mu \mathrm{g} / \mathrm{mL}$ M. l. obtusa venom. Apoptotic cells were evaluated according to nuclear morphology after $\mathrm{H} \& \mathrm{E}$ and PAP staining. In addition to the nuclear morphological changes, giemsa staining showed the bor-

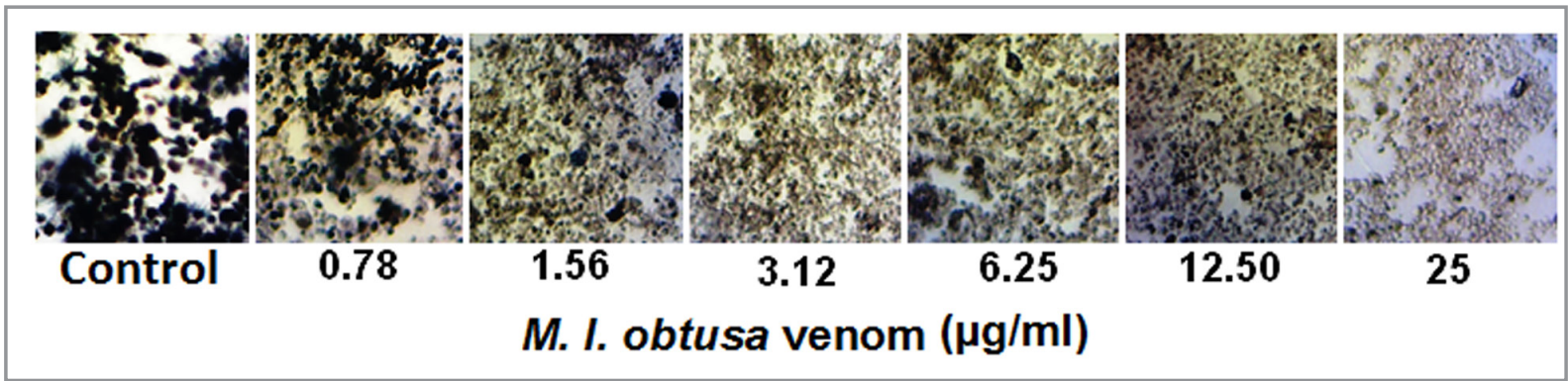

Figure 2. Effect of different venom concentrations on formazan crystal formation after $4 \mathrm{~h}$ incubation with MTT, as observed by light microscope. K562 cells were treated with $0.78-25 \mu \mathrm{g} / \mathrm{mL}$ M. I. obtusa venom for $72 \mathrm{~h}$ (magnification: $\times 40$ ). 
International Journal of Hematology and Oncology

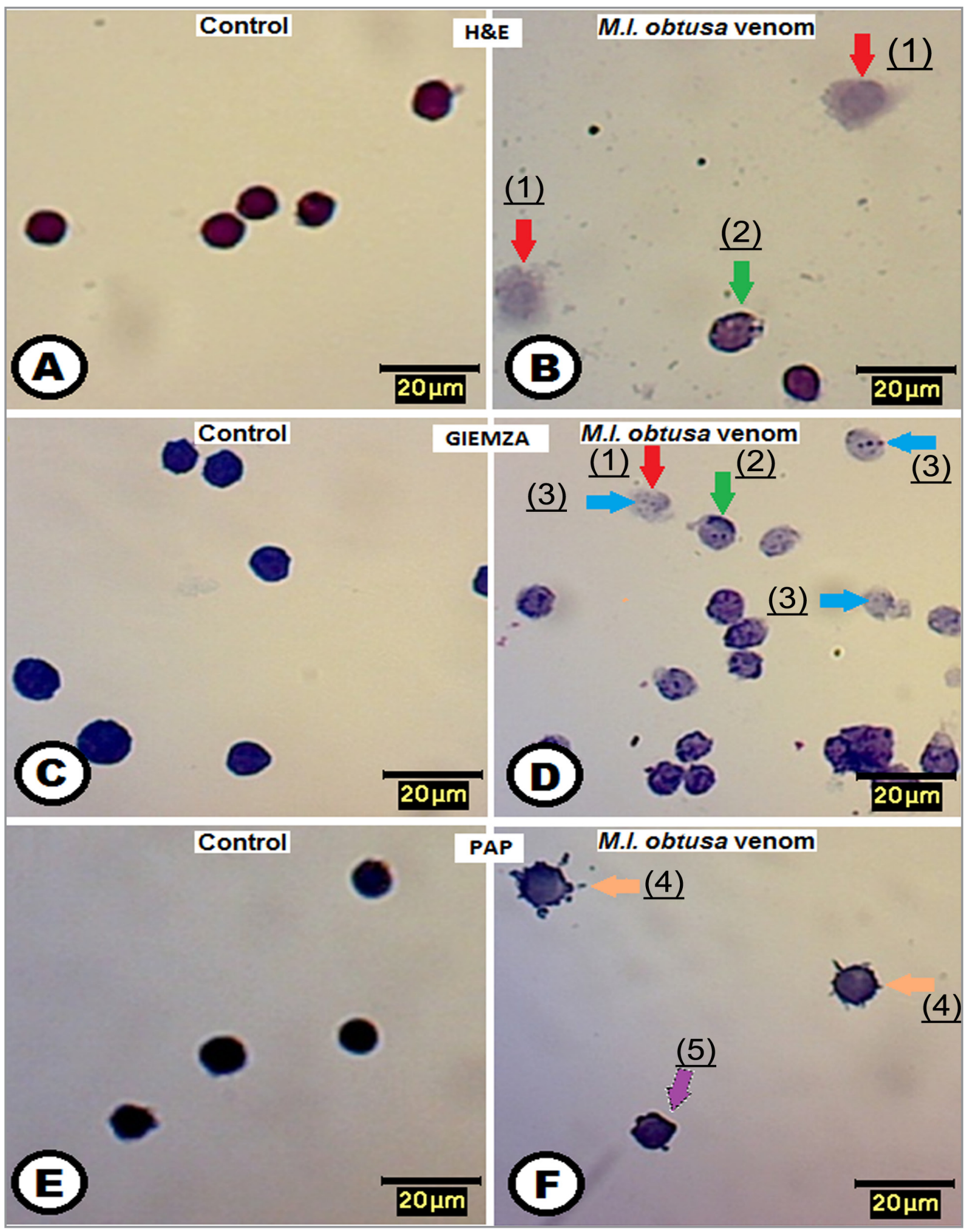

Figure 3. Histological slides of K562 cells examined by light microscopy after $72 \mathrm{~h}$ treatment with $25 \mu \mathrm{g} / \mathrm{mL}$ M. I. obtusa venom with their controls. Cells were stained using routine H\&E (A, B), giemsa (C, D), and PAP (E, F) procedures. Red arrows (no. 1) show phantom cells, which appear in the late stage of apoptosis. Green arrows (no. 2) show chromatin condensation and marginalisation, which is typical for apoptosis. Blue arrows (no. 3) show formation of apoptotic bodies associated with DNA fragmentation during apoptosis induction. Orange arrows (no. 4) show surface blebs, which may have a role in the production of apoptotic bodies. Purple arrow (no. 5) shows cell retraction induced by apoptosis. 


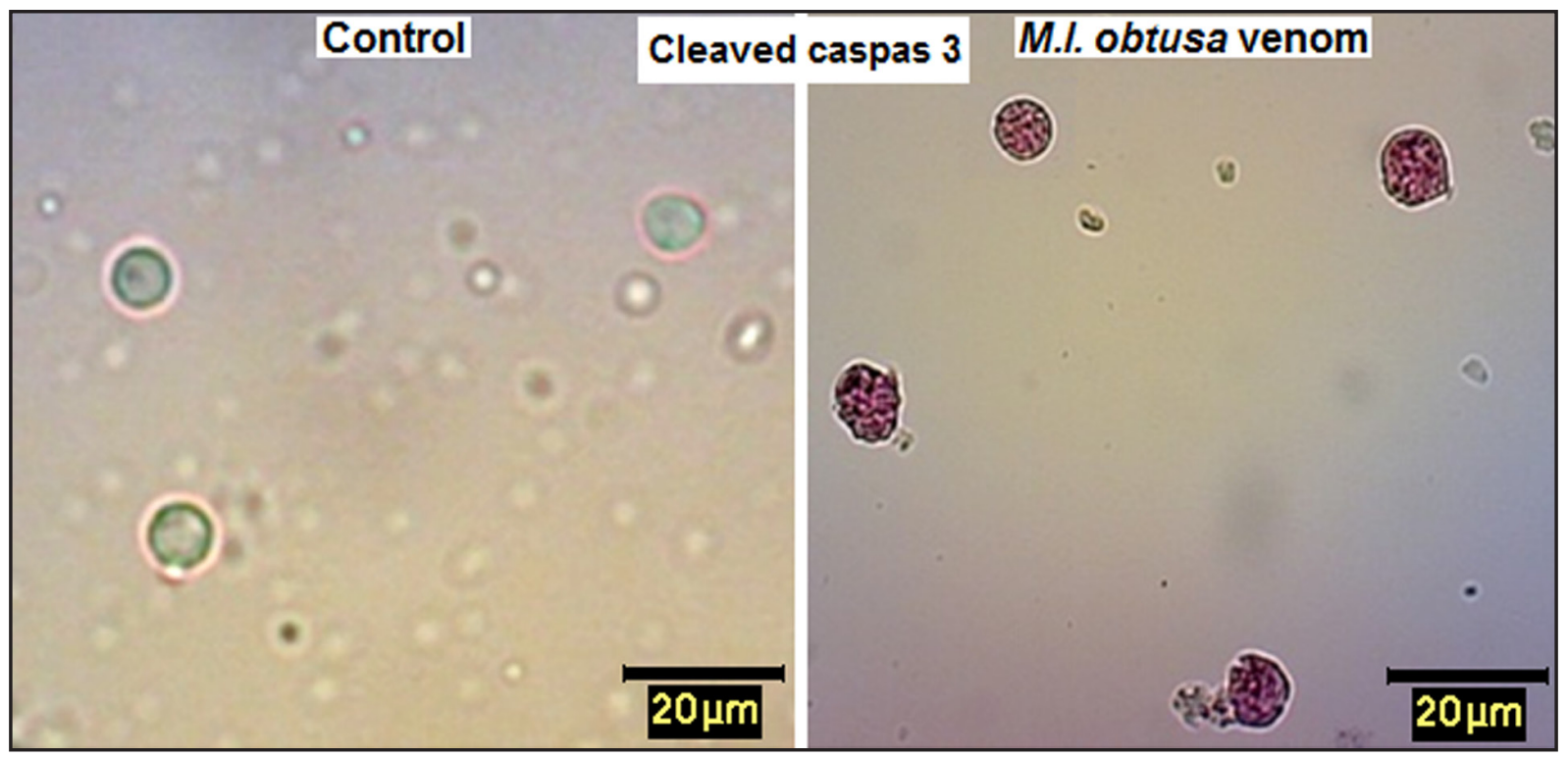

Figure 4. Immunohistochemical staining slides showing the activation of caspase-3 examined by light microscopy after $72 \mathrm{~h}$ treatment with $25 \mu \mathrm{g} / \mathrm{mL}$ M. I. obtusa venom. Refer to methods for the immunohistochemistry procedure. Staining result of the venom treated slide shows the activation of caspase-3, as an indicator of apoptosis induction.

der of the cytoplasm, which provided more information.

At the late stage of apoptosis, nucleus almost disappeared and cells could not be stained, as seen in Figures 3 B, D with red arrows (no. 1). Chromatin condensation and its accumulation at the periphery of the nuclear membrane was observed as shown with green arrows (no. 2) in Figures 3 B, D. We also observed apoptotic bodies (Figure 3 B, D, blue arrows, no. 3), which are the other important morphological changes typical for apoptosis. Moreover, Figure $3 \mathrm{~F}$ shows the surface blebbing (orange arrows, no. 4) and cell retraction (purple arrow, no. 5) in venom treated K562 cells after PAP staining. All these histopathological observations indicated apoptosis induction. ${ }^{32,33}$

In order to confirm the morphological observations indicating the induction of apoptosis at the molecular level, immunohistochemical detection of activated caspase- 3 was performed. As seen in Figure 4, K562 cells after $72 \mathrm{~h}$ treatment with $25 \mu \mathrm{g} / \mathrm{mL}$ M. l. obtusa venom were positively stained by anticleaved caspase-3 antibody while untreated cells did not have reaction with this antibody. The staining corresponding to activated caspase- 3 protein was significantly strong and distributed through the cytoplasm and nuclei with spotted character that reflects apoptosis induction in K562 cells after treatment with M. l. obtusa venom.

\section{DISCUSSION}

Dose-dependent cytotoxic activity of different crude snake venoms and their fractions against various cancer and non-cancerous cell lines have been reported by various researchers..$^{14,20,26,30,34}$ These studies resulted in the description of venom proteins possessing in vitro and/or in vivo anticancer activity, including disintegrin, metalloproteinase, CLP, PLA ${ }_{2}$, and LAAO. Anticancer properties of snake venom proteins and their therapeutic potential have been reviewed recently by various authors. ${ }^{9,35}$

In the present study, the cytotoxicity of M. l. obtusa venom against $\mathrm{K} 562$ cell line was observed and $\mathrm{IC}_{50}$ values were calculated as 0.45 and $0.37 \mu \mathrm{g} / \mathrm{mL}$ by MTT and ATP assays, respectively. Although the results were similar, these two assays could give different results in certain conditions. Therefore, it was suggested to use different methods in combination to assess cytotoxicity. ${ }^{31}$ Selective cytotoxic effect of Anatolian M. lebetina obtusa against various cancer cell lines (not including leukemia) has been reported previously ${ }^{26}$ and shown to be po- 
tent against U-87 MG, MCF-7 and CaCo-2 cells. Hovewer, previous studies revealed that some of the cancer cell lines might show resistancy against crude viper venoms. ${ }^{26,30}$ Therefore, the cytotoxic potency of the venom on various cancer cell lines should be determined by an initial screening study. It has been reported that crude venom of $M$. lebetina (subspecies could be assigned as M. lebetina turanica, according the origin of the samples stated in the paper) inhibited the viability of K562 cells about $10 \%$ after treating with $50 \mu \mathrm{g} / \mathrm{mL}$ of venom for 72 h. ${ }^{19}$ According to our results, M. l. obtusa venom was more potent on K562 cells, compared to $M$. $l$. turanica venom. Debnath et al. ${ }^{14}$ studied the anticarcinogenic activities of Naja kaouthia and Daboia russelli crude venoms on carcinoma, sarcoma and leukemia models, including K562 cells that also was used in the present study. They showed cytotoxic and apoptogenic effect of both venom against $\mathrm{K} 562$ cells. They reported $\mathrm{IC}_{50}$ values as 0.89 and $0.78 \mu \mathrm{g} / \mathrm{mL}$ for $N$. kaouthia and $D$. russelli venoms, respectively, which were close to the ones calculated in the present study. These differences indicated that not only different species, but also subspecies could have cytotoxic potential at different levels. These kind of differences are probably related to variation in venom proteins between different geographic populations of $M$. lebetina. $^{8}$

Proteins with in vitro and in vivo anticancer activities, including metalloproteinase, disintegrin, PLA $_{2}$, LAAO and CLP have been purified and identified in the venom of different subspecies of M. lebetina. ${ }^{13,16,19,36-38}$ These proteins exhibited their cytotoxic effects through different mechanisms such as integrin-blocking and apoptosis induction, resulting in the antiproliferative, antiadhesive and antiangiogenic activities. ${ }^{9}$ A (KTS)disintegrin (lebestatin), CLP (lebectin) and PLA2 purified from the venom of $M$. lebetina inhibited the adhesion and migration of various cancer cell lines, interacting specific integrins. ${ }^{13,36,39}$

Snake venoms have a dual mechanism for their cytotoxic effects. They cause cell death via necrosis and/or apoptosis or autophagy. One of the key mechanisms underlying the anticancer effect of snake venoms is apoptosis. Number of described snake venom proteins, including metalloprotein- ase, disintegrin, CLP, PLA 2 and LAAO, purified from the venom of different species have been shown to induce apoptosis interacting different pathways. ${ }^{12,17-22,40}$

In the present study, preliminary information showing the induction of apoptosis in K562 cells after exposure to M. lebetina obtusa venom was obtained by the observation of the morphological characteristics of apoptosis as well as activation of caspase- 3 by immunohistochemistry. Caspase- 3 is one of the key executioners of apoptosis. ${ }^{32,33}$ There are limited studies investigating the induction of apoptosis in K562 cells, after treatment with crude snake venom or purified proteins. . $^{14,17,19,22,38,41-43}$ Samel et al. ${ }^{19}$ investigated the effect of Sephadex G-100 chromatography fractions of $M$. lebetina turanica (subspecies was not mentioned in the paper but assigned according to the locality) venom and also purified HUVEC apoptosis inducing metalloproteinase (VLAIP). The first fraction reported to inhibit the viability of K562 cells about $30 \%$. The authors reported that this fraction contained LAAO that induced apoptosis in K562 cells, as an unpublished result. However, they did not observe anti-proliferative effect of VLAIP. Additionally, LAAO purified from $M$. lebetina venom has antiplatelet and antibacterial effects. ${ }^{37}$ Proapoptotic properties of LAAOs from other species on various cancers and non-cancerous cell lines have also been shown. ${ }^{12,42} \mathrm{PLA}_{2}$ from the venoms of M. lebetina turanica, Vipera berus berus and Naja naja oxiana have shown to inhibit the viability of K562 cells selectively among other cancer cell lines (LnCaP, PC-3, MCF-7, B10-F16); however, PLA 2 from $M$. lebetina turanica had only a slight effect compared to the other two species. ${ }^{38}$

Conceição et al. ${ }^{43}$ reported that jararhagin, a P-III metalloproteinase from the venom of Bothrops jararaca decreased the viability of K562 cells via inducing autophagy and apoptosis. Debnath et al. ${ }^{14}$ reported apoptotic activity in K562 cells after treatment with $N$. kaouthia and D. russelli crude venoms, according to their morphological observations. In addition, it has been shown that the treatment of K562 cells with cardiotoxin III (a polypeptide with 60 amino acid residues) from the venom of Naja naja atra resulted in the activation of caspase-3 and caspase-9, cleavage of poly 
(ADP-ribose) polymerase (PARP), loss of mitochondrial membrane potential and early release of cytochrome $\mathrm{c}$ from the mitochondria, without generating reactive oxygen species (ROS). ${ }^{41}$ According to these results, the authors suggested that cardiotoxin III induced apoptosis in K562 cells through ROS-independent mitochondrial dysfunction pathway. Yang et al. ${ }^{22}$ showed that cardiotoxin III-induced apoptosis was mediated by $\mathrm{Ca}^{2+}$-dependent caspase-12 activation in K562 cells. PLA and LAAO from the venom of Vipera berus berus also showed proapoptotic effect on K562 cells. ${ }^{38,42}$ Nunes et al. ${ }^{17}$ reported apoptosis inducing effect of CLP from Bothrops lecurus venom on K562 cells. Furthermore, venoms or purified proteins from different subspecies of M. lebetina also induced apoptosis in other various cancers and non-cancerous cells, through different mechanisms. . $^{18,20,21,44}$

Sanz et al. ${ }^{45}$ identified PLA2, LAAO, metalloproteinase, serine proteinase, natriuretic peptide, disintegrin, BPP and CRISP protein families in the venom of M. l. obtusa from Armenia by mass spectrometry-based proteomics approach. Igci and Demiralp ${ }^{8}$ reported the similar protein content with additions of NGF, VEGF and protease inhibitor for Anatolian M. l. obtusa. These results showed $M$. l. obtusa venom contained all the major protein families reported for viper venoms. Taking into consideration the previous studies showing cytotoxic and apoptosis inducing effects of snake venoms and purified proteins against various cancer cell lines, it might be speculated that the cytotoxic and apoptosis-inducing activities of M. 1. obtusa venom resulted from the various interactions of these proteins (e.g., metalloprotease, disintegrin, LAAO, PLA ${ }_{2}$ ) with different molecular pathways in the cell.

Cancer treatment is an important problem in all over the world. Since many of the chemotherapeutic agents being used in current cancer therapies induce apoptosis in cancer cells, there have been an increasing interest in the discovery of novel apoptosis-inducing agents and natural products are good resources to find these kinds of molecules. ${ }^{46,47}$ Giving the emphasis on leukemia, tyrosine kinase inhibitors that are being used for CML treatment (such as imatinib and nilotinib) also induce apoptosis in cancer cells. ${ }^{48,49}$
This is the first report on the the cytotoxicity of Anatolian Macrovipera lebetina obtusa crude venom against K562 cells showing the apoptosisinducing effect of venom on the same cell line, to the best of authors' knowledge. Elucidation of the detailed molecular mechanism underlying apoptotic effect of M. l. obtusa requires further studies, including protein purification and pathway dissection. The present results could be considered as a report of an initial screening study and suggests that M. l. obtusa venom could be used as a source in order to purify and identify new biologically active proteins and peptides with apoptosis-inducing properties that might have therapeutic potential for CML treatment.

\section{REFERENCES}

1. Stewart BW, Wild CP. World Cancer Report 2014. 1st edition. Lyon, World Health Organization (WHO) International Agency for Research on Cancer; 2014.

2. Siegel R, Naishadham D, Jemal A. Cancer statistics, 2013. CA Cancer J Clin 63: 11-30, 2013.

3. Koeffler HP, Golde DW. Human myeoid leukemia cell lines: A review. Blood 56: 344-350, 1980.

4. Sawyers CL. Chronic myeloid leukemia. N Eng J Med 340: 1330-1340, 1999.

5. Lewis RJ, Garcia ML. Therapeutic potential of venom peptides. Nat Rev Drug Discov 2: 790-802, 2003.

6. Koh DC, Armugam A, Jeyaseelan K. Snake venom components and their applications in biomedicine. Cell Mol Life Sci 63: 3030-3041, 2006.

7. Mackessy SP. The field of reptile toxinology: Snakes, lizards, and their venoms. In: Handbook of Venoms and Toxins of Reptiles. Mackessy SP (ed). 1st edition. CRC Press Taylor \& Francis Group, Florida, 2010: 3-23.

8. Igci N, Demiralp DO. A preliminary investigation into the venom proteome of Macrovipera lebetina obtusa (Dwigubsky, 1832) from Southeastern Anatolia by MALDI-TOF mass spectrometry and comparison of venom protein profiles with Macrovipera lebetina lebetina (Linnaeus, 1758) from Cyprus by 2D-PAGE. Arch Toxicol 86: 441-451, 2012.

9. Calderon LA, Sobrinho JC, Zaqueo KD, et al. Antitumoral activity of snake venom proteins: New trends in cancer therapy. BioMed Res Int 2014: 9, 2014.

10. Fox JW, Serrano SMT. Approaching the golden age of natural product pharmaceuticals from venom libraries: An overview of toxins and toxin derivatives currently involved in therapeutic or diagnostic applications. Curr Pharm Des 13: 2927-2934, 2007.

11. Samy RP, Gopalakrishnakone P, Satyanarayanajois SD, et al. Snake venom proteins and peptides as novel antibiotics against microbial infections. Curr Proteomics 10: 10-28, 2013. 
12. Alves RM, Antonucci GA, Paiva HH, et al. Evidence of caspase-mediated apoptosis induced by L-amino acid oxidase isolated from Bothrops atrox snake venom. Comp Biochem Physiol A Mol Integr Physiol 151: 542-550, 2008.

13. Bazaa A, Luis J, Srairi-Abid N, et al. MVL-PLA2, a phospholipase A2 from Macrovipera lebetina transmediterranea venom, inhibits tumor cells adhesion and migration. Matrix Biol 28: 188-193, 2009.

14. Debnath A, Chatterjee U, Das M, et al. Venom of Indian monocellate cobra and Russell's viper show anticancer activity in experimental models. J Ethnopharmacol 111: 681-684, 2007.

15. Gabriel LM, Sanchez EF, Silva SG, et al. Tumor cytotoxicity of leucurolysin-B, a P-III snake venom metalloproteinase from Bothrops leucurus. J Venom Anim Toxins incl Trop Dis 18: 2433, 2012.

16. Marcinkiewicz C, Weinreb PH, Calvete JJ, et al. Obtustatin: A potent selective inhibitor of $\alpha 1 \beta 1$ integrin in vitro and angiogenesis in vivo. Cancer Res 63: 2020-2023, 2003.

17. Nunes ES, Souza MAA, Vaz AFM, et al. Cytotoxic effect and apoptosis induction by Bothrops leucurus venom lectin on tumor cell lines. Toxicon 59: 667-671, 2012.

18. Park MH, Jo M, Won D, et al. Snake venom toxin from Vipera lebetina turanica induces apoptosis of colon cancer cells via upregulation of ROS- and JNK-mediated death receptor expression. BMC Cancer 12: 228, 2012.

19. Samel M, Trummal K, Siigur E, et al. Effect of HUVEC apoptosis inducing proteinase from Vipera lebetina venom (VLAIP) on viability of cancer cells and on platelet aggregation. Toxicon 60: 648-655, 2012.

20. Shebl RI, Mohamed AF, Ali AE, et al. Cerastes cerastes and Vipera lebetina snake venoms apoptotic - stimulating activity to human breast cancer cells and related gene modulation. J Cancer Sci Ther 4: 317-323, 2012.

21. Son DJ, Park MH, Chae SJ, et al. Inhibitory effect of snake venom toxin from Vipera lebetina turanica on hormone-refractory human prostate cancer cell growth: induction of apoptosis through inactivation of nuclear factor $\mathrm{kB}$. Mol Cancer Ther 6: 675-683, 2007.

22. Yang SH, Chien CM, Chang LS, et al. Cardiotoxin-III induced apoptosis is mediated by Ca2+-dependent caspase-12 activation in K652 cells. J Biochem Mol Toxicol 22: 209-218, 2008.

23. Göçmen B, Arikan H, Çiçek K, et al. A serological comparison of the populations of the Levantine Viper, Macrovipera lebetina (Linnaeus, 1758) in Cyprus and southern Turkey. North-West J Zool 3: 75-80, 2007.

24. Arikan H, Göçmen B, Kumlutas $Y$, et al. Electrophoretic characterisation of the venom samples obtained from various Anatolian snakes (Serpentes: Colubridae, Viperidae, Elapidae). North-West J Zool 4: 16-28, 2008.

25. Arikan H, Göçmen B, Igci N, et al. Age-dependent variations in the venom proteins of Vipera kaznakovi Nikolsky, 1909 and Vipera ammodytes (Linnaeus, 1758) (Ophidia: Viperidae). Turk J Zool 38: 216-221, 2014.
26. Ozen $\mathrm{MO}$, Igci $\mathrm{N}$, Yalçin $\mathrm{HT}$, et al. Screening of cytotoxic and antimicrobial activity potential of Anatolian Macrovipera lebetina obtusa (Ophidia: Viperidae) crude venom. Front Life Sci 2015 Jun 19. doi: 10.1080/21553769.2015.1055862

27. Nalbantsoy A, Karabay-Yavasoglu NU, Sayim F, et al. Determination of in vivo toxicity and in vitro cytotoxicity of venom from the Cypriot blunt-nosed viper Macrovipera lebetina lebetina and antivenom production. J Venom Anim Toxins incl Trop Dis 18: 208-216, 2012.

28. Nalbantsoy A, Baykan Erel S, Koksal C, et al. Viper venom induced inflammation with Montivipera xanthina (Gray, 1849) and the anti-snake venom activities of Artemisia absinthium L. in rat. Toxicon 65: 34-40, 2013.

29. Topyildiz H, Hayretdag S. Histopathological effects of Montivipera xanthina venom on rats. Turk J Zool 36: 517-525, 2012.

30. Yalcin HT, Ozen MO, Gocmen B, et al. Effect of Ottoman viper (Montivipera xanthina (Gray, 1849)) venom on various cancer cells and on microorganisms. Cytotechnology 66: 87-94, 2014.

31. Ulukaya E, Ozdikicioglu F, Oral AY, et al. The MTT assay yields a relatively lower result of growth inhibition than the ATP assay depending on the chemotherapeutic drugs tested. Toxicol in Vitro 22: 232-239, 2008.

32. Degterev A, Boyce M, Yuan J. A decade of caspases. Oncogene 22: 8543-8567, 2003.

33. Hengartner MO. The biochemistry of apoptosis. Nature 407: 770-776, 2000.

34. Jamunaa A, Vejayan J, Halijah I, et al. Cytotoxicity of Southeast Asian snake venoms. J Venom Anim Toxins incl Trop Dis 18: 150-156, 2012

35. Jain D, Kumar S. Snake venom: A potent anticancer agent. Asian Pacific J Cancer Prev 13: 4855-4860, 2012.

36. Sarray S, Berthet V, Calvete JJ, et al. Lebectin, a novel C-type lectin from Macrovipera lebetina venom, inhibits integrin-mediated adhesion, migration and invasion of human tumour cells. Lab Invest 84: 573-581, 2004.

37. Tõnismägi K, Samel M, Trummal K, et al. L-Amino acid oxidase from Vipera lebetina venom: Isolation, characterization, effects on platelets and bacteria. Toxicon 48(2): 227-237, 2006.

38. Samel M, Vija H, Kurvet I, et al. Interactions of PLA2-s from Vipera lebetina, Vipera berus berus and Naja naja oxiana venom with platelets, bacterial and cancer cells. Toxins 5: 203-223, 2013.

39. Kallech-Ziri O, Luis J, Daoud S, Bazaa A, et al. Lebestatin, a disintegrin from Macrovipera venom, inhibits integrin mediated cell adhesion, migration and angiogenesis. Lab Invest 85: 1507-1516, 2005.

40. Tanjoni I, Weinlich R, Della-Casa MS, et al. Jararhagin, a snake venom metalloproteinase, induces a specialized form of apoptosis (anoikis) selective to endothelial cells. Apoptosis 10: 851-861, 2005.

41. Yang SH, Chien CM, Lu MC, et al. Cardiotoxin III induces apoptosis in K562 cells through a mitochondrial-mediated pathway. Clin Exp Pharmacol Physiol 32: 515-520, 2005. 
International Journal of Hematology and Oncology

42. Samel M, Vija H, Rönnholm G, et al. Isolation and characterization of an apoptotic and platelet aggregation inhibiting L-amino acid oxidase from Vipera berus berus (common viper) venom. BBA-Proteins Proteom 1764: 707-714, 2006.

43. Conceição TO, Silva MGL, Moreira JALC, et al. Autophagic cell death in human leukemia cells treated with jararhagin toxin, a metaloproteinase analyzed with confocal laser microscopy. In: Microscopy: Advances in Scientific Research and Education. Méndez-Vilas A (ed). 1st edition. Formatex Research Center, Badajoz, 2014: 181-188.

44. Trummal K, Tõnismägi K, Siigur E, et al. A novel metalloprotease from Vipera lebetina venom induces human endothelial cell apoptosis. Toxicon 46: 46-61, 2005.

45. Sanz L, Ayvazyan N, Calvete JJ. Snake venomics of the Armenian mountain vipers Macrovipera lebetina obtusa and Vipera raddei. J Proteomics 71: 198-209, 2008.

46. Gerl L, Vaux DL. Apoptosis in the development and treatment of cancer. Carcinogenesis 26: 263-270, 2005.

47. Taraphdar AK, Roy M, Bhattacharya RK. Natural products as inducers of apoptosis: Implication for cancer therapy and prevention. Curr Sci India 80: 1387-1396, 2001.

48. Belloc F, Moreau-Gaudry F, Uhalde M, et al. Imatinib and nilotinib induce apoptosis of chronic myeloid leukemia cells through a bim-dependant pathway modulated by cytokines. Cancer Biol Ther 6: 912-919, 2007.

49. Jacquel $A$, Herrant M, Legros L, et al. Imatinib induces mitochondria-dependent apoptosis of the Bcr-Abl-positive K562 cell line and its differentiation toward the erythroid lineage. FASEB J 17: 2160-2162, 2003.

\section{Correspondence}

Naşit iĞCl

Nevşehir Hacı Bektaş Veli Üniversitesi

Fen-Edebiyat Fakültesi

Moleküler Biyoloji ve Genetik Bölümü,

50300 Merkez

NEVŞEHIR / TÜRKIYE

Tel: (+90-384) $2281000 / 13159$

e-mail: igcinasit@yahoo.com.tr 